\title{
John E. Skandalakis MD, PhD, FACS (1920-2009)
}

\section{R. Bendavid}

Published online: 1 November 2009

(c) Springer-Verlag 2009

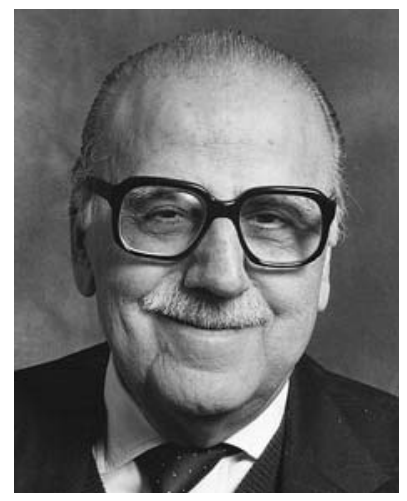

"Wherever the art of medicine is loved, there is also a love of humanity." Hippocrates

The Academy of Athens is a Greek Institution with roots dating back to Plato's school of philosophy (385 BC). Situated at Akademia, north of Athens, it was a sanctuary of Athena, the goddess of wisdom. The Academy of Athens today recognizes achievements in the Arts, Sciences, and Humanities. Those who are so elevated are bestowed the title of "Immortal." John Skandalakis was honored as such an immortal in 1992. I had not been aware of this consecration but I am not surprised, for John symbolized the apothegm: the bluer the blood, the more the humility.

The measure of a man's life can always and accurately be gauged by his contribution. This contribution can be ephemeral, as in sports, entertainment, and business, or everlasting through research, teaching, and publishing in a

R. Bendavid ( $\square)$

614-120 Shelborne Avenue,

Toronto, ON M6B 2M7, Canada

e-mail: rbendavid@ sympatico.ca science which can be edifying and life-saving for generations. If a single life can be saved, the Old Testament tells us, then we have "saved a whole world." John has ideally practiced his art, considerably improved our science, and comforted humanity. Hippocrates is proud. Asklepios, the God of medicine, will welcome him as a member of the Asklepiades.

John Skandalakis was born in 1920, in Molai, Sparta, Greece. He graduated in medicine from the University of Athens (Summa Cum Laude) in 1946. He was certified in General Surgery from the University of Athens in 1950. His training had been at the First Surgical Clinic, Athens University, and at the Naval Hospital in Piraeus, Greece. He retained from that residency a commission with the rank of Lieutenant in the Greek Royal Navy. His extra-curricular activities were anything but peaceful. His patriotic zeal led him to become a member of the underground fighting the Nazi occupation in WWII, an activity for which he received recognition and a medal from the Greek government. After the war, John participated in the fight against communism in what was then a brutal civil war in Greece. A lull in his eventful life was short-lived as he met and married Mimi Cutis of Marietta, Georgia. This was followed by immigration to the United States, a country he was to embrace with all his heart, with an energy which never wavered, and with a fervor that was acknowledged by the Greek government through an award, the Phoenix Medal (1981), which recognized his efforts in improving relations between Greece and the United States. In the United States in 1981, he was made an honorary member of the Daughters of the Revolution.

On the academic front, John never knew an idle moment or boredom. His first duty was to acquire American credentials by furthering his surgical training from 1951 to 1957 at Grady Memorial Hospital, St. Joseph Infirmary and 
Piedmont Hospital in Atlanta. Ever so the impassioned and dedicated student, he furthers his training in anatomy, obtaining a $\mathrm{PhD}$ in this discipline. From then on, he became a founding member of the American Association of Clinical Anatomists (AACA), as well as a founding father of the American Hernia Society (AHS). Keeping in mind the Hippocratic tenet that "Science is the father of knowledge but opinion breeds ignorance," he soon became the driving force behind the creation of the Thalia and Michael Carlos Center for Surgical Anatomy and Technique and more so, the Alfred A. Davis Center for Surgical Anatomy and Research. Along the way, John garnered various titles, such as Professor of Anatomy, Professor of Surgery, Professor of Surgical Anatomy and Technique, Chris Carlos distinguished Professor, and now, to honor him, a John E. Skandalakis Professor of Surgery Chair. His efforts paid off in acquiring University affiliation for the Piedmont Hospital.

In 1981, he was awarded the Aven Cup by the Medical Association of Georgia for outstanding service to the community by a doctor. In 1999, he was rewarded with the distinguished Medical Achievement Award from the Emory School of Medicine. His publications numbered 300 and included classic textbooks in Anatomy, Embryology, and a synopsis of surgical technique for the practicing surgeon and resident.

Although he officially withdrew from active practice in surgery in 1989, it hardly seemed that way as he was busy contributing to conferences and publications, but especially helping aspiring younger surgeons with their publications, research for which John's experience became an invaluable tool.

On a personal note, I met John in 1994, if not earlier, and I was always overwhelmed by his unlimited generosity. His common greeting was always "How are you my brother?" or when parting, "I love you my brother." His only regret and sadness of the last 5-7 years, and which he shared with me, was the trend throughout North America whereby
Anatomy was being taught less and less. Even surgeons were exposed far less than they ought to. In medical schools, few cadavers were prepared simply for demonstration. It seemed to John that a sculptor was acquiring his mastery by looking at pictures of the works of great masters. He even shared with me an editorial he was preparing in which he deplored this new trend. My proudest moment with John was the day that I sent him my translation from French of the Bogros Thesis on a space virtually unknown then in America, the retro-inguinal space that was known as the space of Bogros in France. John called me at the Shouldice Hospital exclaiming: "Who the hell is this Bogros?" Though the space is well known today, it is, unfortunately, poorly understood, and John attempted to clarify the anatomical intricacies. I will be forever grateful to John when he orchestrated a telephone conversation with Omar Askar of Cairo, Egypt, for I had many questions. Subsequently, Omar Askar provided me with his tremendous knowledge of the anatomy of the abdominal wall and especially the midline. Omar Askar's work and John's have figured extensively in all of my attempts at publication, and I would like to register again my everlasting gratitude. Plautus was right when he reminded us that "nothing but heaven is better than a friend who is really a friend."

John had deep religious convictions and was, for 11 years, the President of the Greek Orthodox Cathedral of the Annunciation in Atlanta. His kindness, his generosity, his humanity reminded me of the altruism of the apostles, for John was always aiming very high whenever he wished to emulate anyone!

His family will not be alone in mourning him. His colleagues, his friends, and his coworkers too will grieve. One thing is certain; someone, somewhere, always, a student, a doctor, a surgeon will be poring over his writings, his drawings, his elucidations, so that the name of Skandalakis will become synonymous with anatomy, embryology, and surgery. 